\title{
Effects of supplemental microbial phytase on performance of broiler chickens
}

\author{
Tuomo Kinskinen, Jari PiIronen and Tiina Hakonen
}

\begin{abstract}
Kinsinen, T.', Piironen, J. ${ }^{2}$ \& Hakonen, T. ${ }^{1}$ 1994. Effects of supplemental microbial phytase on performance of broiler chickens. Agricultural Science in Finland 3: 457-466. ('Agricultural Research Centre of Finland, FIN-31600 Jokioinen, Finland, and ${ }^{2}$ Alko Ltd. Biotechnology FIN-05200 Rajamäki, Finland.)
\end{abstract}

Three trials were conducted on a total of 5100 broiler chicks (0-5.5 weeks) to study the effects of different microbial phytase (Aspergillus niger) supplementations $(250-1000$ phytase units $=\mathrm{PU} / \mathrm{g})$ on the performance and bone mineralization of birds and on the utilization of phosphorus compared with the effects of mineral $P$ additions as dicalcium phosphate. The basal diets (negative controls) were principally composed of soya bean meal (SBM) and grain (wheat, barley, oats) supplemented with up to $0.10 \%$ mineral P; the positive control diets were supplemented with $0.24-0.30 \%$ mineral $P$.

Compared with the negative control groups, which were fed diets with $0.05 \%$ mineral $\mathrm{P}$ either during the whole rearing period or during the starting period only, phytase addition increased live weight by $4-7 \%$ and feed intake by 3-9\% (Trials 1 and 2). Tibia values indicated that with low mineral P supplementations ( 0.05 and $0.10 \%$ ), phytase additions have a non-significant effect on bone mineralization. If mineral $\mathrm{P}$ is not added, the tibia values show a marked response to phytase (Trial 3). Utilization of P increased from $50.9 \%$ to $60.0 \%$ when phytase (1000 PU/g) was added to the diets without mineral $P$ supplementation (Trial 3). Utilization of $P$ was only $34.5 \%$ in the positive control diet $(0.3 \%$ mineral P). The results were obviously affected by the intrinsic phytase activity in grain and the dietary calcium level, and suggest that, in SBM-grain-based diets with very low $(0.05 \%)$ or no mineral P supplementation, weight gain can be increased by adding phytase up to $1000 \mathrm{PU} / \mathrm{g}$. This supplemented phytase activity is apparently sufficient for adequate bone mineralization.

Key words: phosphorus, phytic acid, growth, feed efficiency, bone mineralization, mineral utilization

\section{Introduction}

Poultry diets principally consist of feeds of plant origin. Significant amount $(50-80 \%)$ of the phosphorus in plant seeds is bound to phytic acid, and the availability for monogastrics such as poultry is low. An availability value of $30 \%$ is assigned for phosphorus in plant materials in common use.
The earliest studies on the effects of supplemental microbial phytase in chickens were those of NELSON et al. (1968b, 1971). These authors concluded that the addition of phytase produced by moulds (Aspergillus ficuum) to the diet of chicks hydrolysed phytate phosphorus in the gastrointestinal tract, enabling the chicks to utilize the liberated phosphorus as well as supplementa- 
ry inorganic phosphorus. In recent years, wide interest has been shown in producing the available microbial phytases in order to lower the supplemental mineral phosphorus and phosphorus content in manure. The addition of microbial phytase (A. ficuum and A. niger) to the diets of poultry, those of growing poultry in particular, has also been studied in greater detail. The addition of phytase to low phosphorus $(0.4-0.5 \%$ total P) diets of chickens and broilers has markedly increased feed intake and growth rate (KIISKINEN and PiIronen 1990, Simons et al. 1990, Swick and IVEY 1990, SAYLOR et al. 1991, SCHÖNER et al. 1991, Broz et al. 1992, SCHÖNER and HoPPE 1992, VoGT 1992a, b, FARRELl et al. 1993, SCHÖNER et al. 1993). At the same time, phytase supplementations have also significantly enhanced bone mineralization measured as bone ash content or improved phosphorus utilization.

Most of the research on phytase additions has been done by studying corn-soya bean meal (SBM) diets. Here we set out to establish what level of supplemental microbial phytase (A. niger) is sufficient in diets containing wheat, barley, oats, SBM and different additions of mineral phosphorus.

\section{Material and methods}

\section{Animals and housing}

Three trials were conducted on 5100 Ross broiler chicks which were sexed and allotted to treatments when one day old. In Trials 1 and 2 the birds were housed in floor pens and in Trial 3 in a 3-tier battery. Housing conditions (temperature, lighting) were as described by KIISKINEN (1983). Peat was used as litter and the experiments lasted for 37,37 and 35 days, respectively. Feed and water were supplied ad libitum.

\section{Experimental design and diets}

Trial 1 comprised eight groups with four replicate pens $\left(6 \mathrm{~m}^{2}\right)$, each holding 60 birds (30 males, 30 females). The basal composition of the SBM-grain
Table 1. Composition $(\%)$ of the basal diets with lowest phosphate addition.

\begin{tabular}{|c|c|c|c|c|}
\hline & \multirow[t]{2}{*}{ Trial 1} & \multicolumn{2}{|c|}{ Trial 2} & \multirow[t]{2}{*}{ Trial 3} \\
\hline & & Starter & Grower & \\
\hline Soya bean meal & 32.0 & 35.0 & 26.0 & 32.0 \\
\hline Wheat & 25.0 & 23.0 & 25.0 & 25.0 \\
\hline Barley & 28.0 & 25.0 & 30.0 & 30.0 \\
\hline Oats & 8.7 & 10.9 & 13.4 & 7.1 \\
\hline Rapeseed oil & 3.0 & 3.0 & 3.0 & 3.0 \\
\hline Limestone & 2.0 & 2.0 & 1.8 & 2.0 \\
\hline Dicalcium phosphate & 0.3 & 0.3 & - & - \\
\hline Sodium chloride & 0.35 & 0.3 & 0.3 & 0.3 \\
\hline $\begin{array}{l}\text { Vitamin and mineral } \\
\text { premixes }^{1)}\end{array}$ & 0.5 & 0.5 & 0.5 & 0.5 \\
\hline DL methionine & 0.08 & 0.08 & 0.08 & 0.08 \\
\hline L lysine & 0.03 & 0.03 & 0.03 & 0.03 \\
\hline Calculated ME MJ $/ \mathrm{kg}$ & 11.55 & 11.50 & 11.75 & 11.60 \\
\hline Analysed dry matter & 87.7 & 88.1 & 87.7 & 90.1 \\
\hline crude protein & 22.5 & 22.2 & 20.4 & 20.7 \\
\hline ether extract & 5.0 & 5.7 & 5.4 & 5.2 \\
\hline crude fibre & 4.5 & 4.6 & 3.7 & 4.4 \\
\hline ash & 4.8 & 4.9 & 4.6 & 4.8 \\
\hline
\end{tabular}

1) Supplied per kilogram of diet: $14000 \mathrm{IU}$ vitamin A, $1700 \mathrm{IU}$ vitamin D, $30 \mathrm{mg}$ vitamin $\mathrm{E}, 1 \mathrm{mg}$ vitamin $\mathrm{K}$, $1 \mathrm{mg}$ thiamin, $6 \mathrm{mg}$ riboflavin, $20 \mu \mathrm{g}$ vitamin $\mathrm{B}_{12}, 3 \mathrm{mg}$ pyridoxine, $40 \mathrm{mg}$ niacin, $10 \mathrm{mg}$ pantothenic acid, $0.5 \mathrm{mg}$ folic acid, $0.3 \mathrm{mg}$ biotin, $500 \mathrm{mg}$ choline cloride, $20 \mathrm{mg}$ $\mathrm{Fe}, 30 \mathrm{mg} \mathrm{Zn,} 50 \mathrm{mg} \mathrm{Mn}, 5 \mathrm{mg} \mathrm{Cu}, 0.5 \mathrm{mg} \mathrm{I}$

diets (Table 1) was similar for all groups excluding supplementations, which were as follows:

\begin{tabular}{lrrrrrrrr} 
Group & 1 & 2 & 3 & 4 & 5 & 6 & 7 & 8 \\
\hline Phytase PU/g & 0 & 250 & 500 & 500 & 500 & 750 & 1000 & 0 \\
Mineral P\% & 0.05 & 0.05 & 0.05 & 0.13 & 0.21 & 0.05 & 0.05 & 0.30
\end{tabular}

Microbial phytase was produced by Alko Biotechnology (Rajamäki, Finland). One PU (phytase unit) is the amount of enzyme that liberates one nmol of inorganic $\mathrm{P}$ from sodium phytate per minute at $\mathrm{pH} 5$ and $37^{\circ} \mathrm{C}$. The added mineral $\mathrm{P}$ was derived from dicalcium phosphate in all trials.

The calculated contents of $\mathrm{Ca}$ and $\mathrm{P}$ were $0.96-$ $0.97 \%$ and $0.45-0.71 \%$, respectively (Table 2 ). The lowest dietary level of available phosphorus 
Table 2. Calcium and phosphorus contents of diets.

\begin{tabular}{|c|c|c|c|c|c|c|c|}
\hline & & \multirow{2}{*}{$\begin{array}{c}\text { Added } \\
\text { dicalcium } \\
\text { phosphate } \\
\%\end{array}$} & \multicolumn{2}{|c|}{$\begin{array}{c}\text { Calcium } \\
\%\end{array}$} & \multicolumn{2}{|c|}{$\begin{array}{c}\text { Phosphorus } \\
\%\end{array}$} & \multirow{2}{*}{$\begin{array}{c}\text { Available } \\
\text { P \% } \\
\text { Calc. }\end{array}$} \\
\hline & & & Calc. & Anal. & Calc. & Anal. & \\
\hline \multicolumn{8}{|c|}{ Trial 1} \\
\hline Diets & $1-3$ & 0.3 & 0.97 & 0.91 & 0.45 & 0.49 & 0.17 \\
\hline$"$ & 4 & 0.75 & 0.96 & 0.88 & 0.53 & 0.56 & 0.25 \\
\hline$"$ & 5 & 1.25 & 0.97 & 0.88 & 0.61 & 0.66 & 0.33 \\
\hline$"$ & $6-7$ & 0.3 & 0.97 & 0.92 & 0.45 & 0.52 & 0.17 \\
\hline$"$ & 8 & 1.35 & 0.96 & 0.87 & 0.71 & 0.78 & 0.45 \\
\hline \multirow{2}{*}{\multicolumn{8}{|c|}{$\begin{array}{l}\text { Trial } 2 \\
\text { Starters }\end{array}$}} \\
\hline & & & & & & & \\
\hline Group & $1-3$ & 0.3 & 0.97 & 0.99 & 0.45 & 0.50 & 0.17 \\
\hline$"$ & $4-5$ & 0.6 & 0.97 & 0.98 & 0.50 & 0.56 & 0.22 \\
\hline$"$ & 6 & 1.7 & 0.99 & 1.04 & 0.69 & 0.72 & 0.41 \\
\hline \multicolumn{8}{|c|}{ Growers } \\
\hline Group & $1-3$ & - & 0.80 & 0.81 & 0.37 & 0.44 & 0.11 \\
\hline$"$ & $4-5$ & 0.3 & 0.80 & 0.79 & 0.42 & 0.49 & 0.16 \\
\hline$"$ & 6 & 1.4 & 0.81 & 0.77 & 0.61 & 0.67 & 0.35 \\
\hline \multicolumn{8}{|c|}{ Trial 3} \\
\hline Diets & $1-2$ & - & 0.88 & 1.00 & 0.42 & 0.48 & 0.16 \\
\hline$"$ & $3-5$ & 0.3 & 0.88 & 1.01 & 0.47 & 0.55 & 0.21 \\
\hline$"$ & $6-7$ & 0.6 & 0.89 & 1.00 & 0.52 & 0.60 & 0.26 \\
\hline$"$ & 8 & 1.6 & 0.92 & 1.05 & 0.69 & 0.79 & 0.43 \\
\hline
\end{tabular}

(AP) was $0.17 \%$ and the highest level $0.45 \%$ (positive control). The latter value represents the practical dietary level and complies with recommendations (NRC 1984, SALO et al. 1990). The diets in this trial and the other two were cold (about $50^{\circ} \mathrm{C}$ ) pelleted without hot steam.

Trial 2 was conducted on six groups with eight replicates (62 birds) each. The pens were smaller $\left(4 \mathrm{~m}^{2}\right)$ than those in Trial 1 , and half of them contained males and half females. The chicks were first fed a starter diet ( $0-2.5$ weeks) and then a grower diet (2.5-5.5 weeks) (Table 1). The experimental groups with dietary supplementations were as follows:

\begin{tabular}{lrrrccr} 
Group & 1 & 2 & 3 & 4 & 5 & 6 \\
\hline $\begin{array}{l}\text { Phytase PU/g } \\
\text { Mineral P\% }\end{array}$ & 0 & 500 & 1000 & 0 & 500 & 0 \\
$\quad$ in starter & 0.05 & 0.05 & 0.05 & 0.10 & 0.10 & 0.29 \\
$\quad$ in grower & 0 & 0 & 0 & 0.05 & 0.05 & 0.24
\end{tabular}

The calculated mineral contents in the starters were $0.97-0.99 \%$ for $\mathrm{Ca}, 0.45-0.69 \%$ for $\mathrm{P}$ and $0.17-0.41 \%$ for AP (Table 2). The corresponding levels in the growers were $0.80-0.81 \%, 0.37-$ $0.61 \%$ and $0.11-0.35 \%$, respectively.

The main purpose of Trial 3 was to determine the retention of $\mathrm{P}$ with basal diets similar to those used in Trials 1-2. Six replicate cages with four birds in each were allotted for each diet. The supplementations were as follows:

\begin{tabular}{lrrrrrrrr} 
Group & 1 & 2 & 3 & 4 & 5 & 6 & 7 & 8 \\
\hline Phytase PU/g & 0 & 1000 & 0 & 500 & 1000 & 0 & 500 & 0 \\
Mineral P\% & 0 & 0 & 0.05 & 0.05 & 0.05 & 0.10 & 0.10 & 0.30
\end{tabular}

The $\mathrm{Ca}$ and $\mathrm{P}$ contents are listed in Table 2. The calculated Ca levels were $0.88-0.92 \%$, the total P levels $0.42-0.69 \%$ and the AP levels 0.16$0.43 \%$. 
Measurements, chemical analyses and statistics

In Trials 1-2 the birds were weighed pen by pen when one day old. At days 16 and 37, the birds were weighed either individually (Trial 1) or pen by pen (Trial 2). The birds in Trial 3 were weighed individually when one day and 35 days old. Feed intake per replicate (pen, cage) was measured between the weighings. The chickens were starved for 12 hours before slaughter. Dead birds were recorded and weighed. In the slaughter house, 16 carcasses were taken from each group. Both tibias were removed and cleaned before being measured for length and weight (Trial 3 ) and analysed for ash and phosphorus (Trial 1) contents.

In Trial 3, the retention of $\mathrm{P}$ and $\mathrm{Ca}$ was determined when the chicks were four weeks old. Weighed amounts of diets were supplied daily, and all excreta were collected over three days. The excreta were weighed, oven-dried at $60^{\circ} \mathrm{C}$ and ground before analysis.

Proximate feed $\mathrm{Ca}$ and $\mathrm{P}$ analyses were performed for the experimental diets. Calcium and $\mathrm{P}$ were also analysed in cereals. Calcium was analysed with an atomic absorption spectrophotometer and $\mathrm{P}$ with a photometer after a colour reaction with ammonium vanadate. The same method was used to determine the $\mathrm{P}$ concentration in tibia ash. The cleaned tibias were ashed at $600^{\circ} \mathrm{C}$ 16 hours after crushing and ether extraction.

The phytic acid content and phytase activity in cereals were determined in Alko's laboratory. Phytic acid (inositol hexaphosphate) was separated after $\mathrm{HCl}$ extraction by ion exchange and analysed by ion pair $\mathrm{C}_{18}$ reverse phase HPLC (SANDBERG and Ahderinne 1986). Phytase activity was determined from the colour formed by the reduction of a phosphomolybdate complex (CHEN et al. 1956). A phytase unit (PU) is the amount of enzyme which liberates, under standard conditions, $1 \mathrm{nmol}$ of inorganic phosphate from sodium phytate in one minute.

Analysis of variance was used for the statistical inference. The basic idea of analysis of variance is to divide the total variation in the re- sponse variable into portions associated with certain factors defined by the scheme used for classifying the data. Here, these factors or sources of variation were primarily the treatments and the sex of the birds. The experimental unit for the treatments in all the trials was a pen or a cage, and in Trial 2, in particular, the experimental unit for a treatment and sex combination was a pen. In Trials 1 and 3, the birds were weighed individually, and the males and females were not separated into different pens; the experimental unit for the sex of the bird was a bird. Some of the birds died before the experiments were finished, and from the beginning of the trials there were uneven numbers of males and females in some of the pens or cages. This resulted in unbalanced experiments. In such situations, residual maximum likelihood (REML) estimates were used as suggested by MiLLIKEN and JOHNSON (1984) instead of the usual moment estimates. The SAS MIXED-procedure (SAS 1992) was used for analysing the unbalanced data and the SAS GLM procedure (SAS 1990) for the balanced data.

The main interest in terms of statistical inference lay in the contrast analysis. In Trial 1, orthogonal polynomials were used to investigate the trends over levels of phytase when the level of mineral $\mathrm{P}$ was $0.05 \%$. Linear, quadratic, cubic and even quartic trends were tested. In Trial 2, the main interest was in comparing the two levels of phytase, namely 0 and $500 \mathrm{PU} / \mathrm{g}$ and to compare the two levels of mineral $\mathrm{P}$ combinations, namely $0.05 \% / 0 \%$ and $0.10 \% / 0.05 \%$ (in starter/in grower). The phytase $\mathrm{x}$ phosphorus interaction was also tested. In Trial 3, two trends were of interest. In groups where the mineral $\mathrm{P}$ concentration was $0.05 \%$ the linear and quadratic trends over phytase levels were tested; when phytase was $0 \mathrm{PU} / \mathrm{g}$ the linear and quadratic trends over the levels of mineral $\mathrm{P}$ were tested.

\section{Results and discussion}

The analysed total P contents of the diets $(0.44$ $0.79 \%$ ), which were higher than the calculated ones (Table 2) were derived from the P contents 
Table 3. Ca, $\mathrm{P}$ and phytin-P contents and phytase activity in cereals and soya bean meal.

\begin{tabular}{|c|c|c|c|c|c|}
\hline & $\mathrm{Ca}$ & ter $^{P}$ & $\begin{array}{l}\text { Phytic } \\
\text { acid } 1) \\
\%\end{array}$ & $\begin{array}{l}\text { P\% bound } \\
\text { in phytic } \\
\text { acid }\end{array}$ & $\begin{array}{c}\text { Phytase } \\
\text { acitivity } \\
\text { PU/g DM }^{2)}\end{array}$ \\
\hline \multicolumn{6}{|l|}{ Trial 1} \\
\hline Wheat & 0.044 & 0.43 & 0.55 & 0.16 & 560 \\
\hline Barley & 0.046 & 0.44 & 0.61 & 0.17 & 480 \\
\hline Oats & 0.065 & 0.42 & 0.49 & 0.14 & 65 \\
\hline Soya bean meal & 0.331 & 0.67 & 0.91 & 0.26 & 5 \\
\hline \multicolumn{6}{|l|}{ Trial 2} \\
\hline Wheat & 0.041 & 0.42 & - & - & 625 \\
\hline Barley & 0.043 & 0.45 & - & - & 235 \\
\hline Oats & 0.071 & 0.40 & - & - & 29 \\
\hline Soya bean meal & 0.245 & 0.76 & - & - & - \\
\hline
\end{tabular}

$(0.40-0.45 \%$ in dry matter, Table 3$)$ of the cereals which were higher than the content $(0.35 \%)$ used in the calculations (SALO et al. 1990). The cereals in the diets of Trial 1 contained 0.49 $0.61 \%$ phytic acid, which amounts to $0.14-0.17 \%$ phytate P (Table 3). Phytate P accounted for 37$39 \%$ of the total P of grain, which is lower than the $56-73 \%$ presented by NELSON et al. (1968a) and LANTZSCH (1990). Soya bean meal (Trial 1) contained $0.91 \%$ phytic acid and $0.26 \%$ phytate $\mathrm{P}$, or $39 \%$ of total P. This figure too is lower than the $56-61 \%$ given by the above authors.

Phytase activity in grain was highest in wheat and lowest in oats (Table 3). The order of the cereals is consistent with the findings of MøLLGAARD et al. (1946). From the proportions of cereals in the basal diets of Trials 1 and 2, the natural phytase activities of the diets should have been 280 and 205-230 PU/g, respectively. According to the phytase activity determined in the diets of Trial 2 (750-1200 PU/g depending on the supplementation), the intrinsic activity of phytase in the diets was 200-250 PU/g.

In all trials, chicks fed the phytase supplemented diets gained more weight than those fed the diets with no or very low $(0.05 \%)$ additional phosphorus (Tables 4-6). Compared with the negative control groups fed a supplementary level of $0.05 \%$ mineral $\mathrm{P}$ throughout the growing period or in the starter diet only the phytase additions increased final body weight by $4-7 \%$ (Tables 4 and 5). Orthogonal polynomial comparison showed a linear effect of phytase additions on live weight at $16(\mathrm{P}<0.001)$ and 37 days $(\mathrm{P}<0.01)$ in Trial 1. Also in Trial 2, phytase significantly $(\mathrm{P}<0.05)$ increased final body weight, and its effect on the 16-day weight approached significance $(\mathrm{P}<0.07)$. It would seem that positive growth responses might be obtained with phytase supplementations of up to $1000 \mathrm{PU} / \mathrm{g}$. The same growth rate was found by adding $0.10 \%$ or $0.13 \%$ inorganic $P$ and $500 \mathrm{PU} / \mathrm{g}$ phytase (Tables 4 and 5). A significant $(\mathrm{P}<0.05)$ difference between the $\mathrm{P}$ supplementations of $0.05 \%$ and $0.10 \%$ was noted in Trial 2 . The phytase $\mathrm{x}$ phosphorus interaction was not found in that trial. The treatment $x$ sex interaction in growth rate was not found in Trials 1 and 2. Certain combinations of supplemental phytase and mineral $\mathrm{P}$ gave similar and even higher final body weights than the supplemental mineral $\mathrm{P}$ levels of $0.24-0.30 \%$ in the positive control diets. Most previous studies with phytase have been done using corn-based diets in which the activity of natural phytase is relatively low. Therefore, when added to corn-based low-phosphorus diets (0.35-0.55\% total P), phytase supplementations have produced weight gains in broilers (4-6 weeks) up to $15-47 \%$ higher than those obtained 
Table 4. Performance of birds and tibia values (Trial 1).

\begin{tabular}{|c|c|c|c|c|c|c|c|c|c|}
\hline \multirow{3}{*}{$\begin{array}{l}\text { Diet } \\
\text { Mineral P add. \% } \\
\text { Phytase add. PU/g }\end{array}$} & 1 & 2 & 3 & 4 & 5 & 6 & 7 & 8 & SE \\
\hline & 0.05 & 0.05 & 0.05 & 0.13 & 0.21 & 0.05 & 0.05 & 0.30 & \\
\hline & 0 & 250 & 500 & 500 & 500 & 750 & 1000 & 0 & \\
\hline \multirow{2}{*}{$\begin{array}{ll}\text { Live weight g } & 16 \text { days } \\
& \end{array}$} & 418 & 450 & 476 & 495 & 484 & 474 & 504 & 478 & 8.6 \\
\hline & 1629 & 1695 & 1697 & 1742 & 1742 & 1706 & 1744 & 1673 & 22.0 \\
\hline & 34.3 & 38.0 & 39.1 & 40.8 & 39.8 & 38.7 & 40.9 & 39.3 & 1.26 \\
\hline g/day $17-37$ ", & 116 & 125 & 123 & 125 & 127 & 125 & 126 & 125 & 1.26 \\
\hline \multirow{3}{*}{$\begin{array}{lr}\text { FCR } & 1-16 " \\
\mathrm{~kg} / \mathrm{kg} & 17-37 "\end{array}$} & 1.46 & 1.48 & 1.44 & 1.44 & 1.44 & 1.44 & 1.41 & 1.44 & 0.024 \\
\hline & 2.06 & 2.10 & 2.12 & 2.10 & 2.11 & 2.12 & 2.13 & 2.21 & 0.024 \\
\hline & 1.91 & 1.95 & 1.94 & 1.92 & 1.93 & 1.94 & 1.94 & 2.00 & 0.020 \\
\hline \multirow{2}{*}{$\begin{array}{l}\text { Mortality \% 1-37 } \\
\text { Tibia }\end{array}$} & 7.3 & 4.6 & 4.2 & 3.3 & 3.3 & 4.6 & 3.3 & 3.8 & 0.44 \\
\hline & \\
\hline length $\mathrm{cm}$ & 8.9 & 9.0 & 9.1 & 9.3 & 9.2 & 9.2 & 9.2 & 9.0 & 0.10 \\
\hline ash \% & 54.9 & 54.9 & 55.1 & 54.9 & 55.4 & 54.8 & 55.2 & 55.7 & 0.43 \\
\hline $\mathrm{P} \%$ in ash & 19.5 & 19.9 & 19.9 & 20.1 & 20.1 & 20.1 & 19.8 & 19.6 & 0.09 \\
\hline
\end{tabular}

$\mathrm{SE}=$ standard error of mean

$\mathrm{FCR}=$ feed conversion ratio

with the basal diets (SimONS et al. 1990, Swick and IVEY 1990, Vogt 1992a, b, SCHÖNER and HOPPE 1992, SCHÖNER et al. 1993). When wheat has been included in the diets, the growth responses have been comparable to the results of our study (ZYLA et al. 1989, SCHÖNER and HOPPE 1992, BROZ et al. 1992).
The faster growth of the birds fed the phytase supplemented diets or the positive control diets was largely due to their feed intake being higher than that of the negative controls (Tables 4-6). In Trial 1 , the daily feed intake increased linearly $(\mathrm{P}<0.001)$ as a result of phytase addition. The same happened in Trial 2 owing to phytase addi-

Table 5. Performance of birds and tibia values (Trial 2).

\begin{tabular}{|c|c|c|c|c|c|c|c|}
\hline Diet & 1 & 2 & 3 & 4 & 5 & 6 & \\
\hline Mineral $\mathrm{P}$ add. $\%$ in starter & 0.05 & 0.05 & 0.05 & 0.10 & 0.10 & 0.29 & \\
\hline$" \quad, \quad "$ grower & - & - & - & 0.05 & 0.05 & 0.24 & \\
\hline Phytase add. PU/g & - & 500 & 1000 & - & 500 & - & SE \\
\hline \multirow{2}{*}{$\begin{array}{ll}\text { Live weight } \mathrm{g} & 16 \text { days } \\
& \\
37 & "\end{array}$} & 496 & 518 & 517 & 510 & 515 & 530 & 7.5 \\
\hline & 1611 & 1680 & 1710 & 1687 & 1733 & 1749 & 18.0 \\
\hline Feed intake $1-16 "$ & 41.4 & 43.6 & 43.8 & 42.7 & 43.4 & 45.2 & 1.06 \\
\hline g/day $17-37 "$ & 113 & 116 & 118 & 118 & 120 & 127 & 1.06 \\
\hline \multirow{3}{*}{$\begin{array}{lr}\text { FCR } & 1-16 ", \\
\mathrm{~kg} / \mathrm{kg} & 17-37 " \\
& 1-37 "\end{array}$} & 1.47 & 1.47 & 1.48 & 1.46 & 1.44 & 1.48 & 0.017 \\
\hline & 2.15 & 2.13 & 2.08 & 2.13 & 2.08 & 2.20 & 0.017 \\
\hline & 1.95 & 1.93 & 1.91 & 1.93 & 1.90 & 1.99 & 0.013 \\
\hline \multirow{2}{*}{$\begin{array}{l}\text { Mortality \% 1-37", } \\
\text { Tibia }\end{array}$} & 3.8 & 5.2 & 3.6 & 3.0 & 7.9 & 3.8 & 0.55 \\
\hline & & & & & & & \\
\hline \multirow{2}{*}{$\begin{array}{l}\text { length } \mathrm{cm} \\
\text { ash \% }\end{array}$} & 9.2 & 9.2 & 9.2 & 9.2 & 9.3 & 9.2 & 0.08 \\
\hline & 53.8 & 54.8 & 54.7 & 55.2 & 55.1 & 56.1 & 0.35 \\
\hline
\end{tabular}

$\mathrm{SE}=$ standard error of mean

$\mathrm{FCR}=$ feed conversion ratio 
Table 6. Performance of birds, tibia values and utilization of minerals (Trial 3).

\begin{tabular}{|c|c|c|c|c|c|c|c|c|c|}
\hline Diet & 1 & 2 & 3 & 4 & 5 & 6 & 7 & 8 & SE \\
\hline Mineral $\mathrm{P}$ add. \% & - & - & 0.05 & 0.05 & 0.05 & 0.10 & 0.10 & 0.3 & \\
\hline Phytase add. PU/g & - & 1000 & - & 500 & 1000 & - & 500 & - & \\
\hline Live weight g 35 days & 1135 & 1460 & 1451 & 1502 & 1490 & 1538 & 1522 & 1498 & 39.6 \\
\hline Feed intake g/bird/d & 54 & 70 & 72 & 72 & 74 & 77 & 74 & 74 & 1.54 \\
\hline $\mathrm{FCR} \mathrm{kg/kg}$ & 1.89 & 1.81 & 1.88 & 1.82 & 1.83 & 1.87 & 1.83 & 1.82 & 0.03 \\
\hline \multicolumn{10}{|l|}{ Tibia } \\
\hline weight g & 7.2 & 11.0 & 9.8 & 11.0 & 11.2 & 10.9 & 12.1 & 11.5 & 0.58 \\
\hline length $\mathrm{cm}$ & 7.8 & 8.6 & 8.6 & 8.8 & 8.7 & 8.7 & 8.8 & 8.8 & 0.10 \\
\hline ash \% & 51.0 & 55.1 & 55.6 & 56.1 & 56.8 & 56.5 & 56.8 & 56.8 & 0.37 \\
\hline \multicolumn{10}{|c|}{ Apparent retention of $\mathrm{P}$ and $\mathrm{Ca}$} \\
\hline$P$ intake $g$ & 4.7 & 6.5 & 7.2 & 7.2 & 7.4 & 8.1 & 8.3 & 10.9 & 0.17 \\
\hline Faecal P excretion $\mathrm{g}$ & 2.3 & 2.6 & 3.5 & 3.6 & 3.6 & 4.7 & 4.6 & 7.2 & 0.13 \\
\hline$P$ retention $\mathrm{g}$ & 2.4 & 3.9 & 3.7 & 3.6 & 3.8 & 3.4 & 3.5 & 3.7 & 0.13 \\
\hline $\mathrm{P}$ retention \% & 50.9 & 60.0 & 50.6 & 50.1 & 51.0 & 42.3 & 42.8 & 33.9 & 1.34 \\
\hline Faecal P g/kg DM & 7.7 & 6.7 & 8.5 & 9.0 & 9.0 & 10.5 & 11.1 & 16.5 & 0.24 \\
\hline $\mathrm{Ca}$ intake $\mathrm{g}$ & 9.7 & 13.5 & 13.0 & 13.1 & 14.0 & 13.7 & 13.8 & 14.7 & 0.32 \\
\hline Faecal $\mathrm{Ca}$ excretion $\mathrm{g}$ & 6.0 & 7.7 & 7.6 & 7.8 & 8.2 & 8.8 & 8.8 & 9.2 & 0.28 \\
\hline Ca retention $\mathrm{g}$ & 3.7 & 5.8 & 5.4 & 5.3 & 5.8 & 4.9 & 5.0 & 5.5 & 0.21 \\
\hline Ca retention \% & 38.2 & 43.0 & 41.2 & 40.7 & 41.7 & 36.2 & 36.6 & 37.5 & 1.35 \\
\hline
\end{tabular}

$\mathrm{SE}=$ standard error of mean

$\mathrm{FCR}=$ feed conversion ratio

tion $(500 \mathrm{PU} / \mathrm{g}, \mathrm{P}<0.05)$ and the higher dietary $\mathrm{P}$ level $(\mathrm{P}<0.01)$. In the supplemented groups of Trial 1, the feed conversion ratio (FCR) was slightly, but not significantly, higher than that of the negative control group (Table 4). In contrast, in Trial 2 the FCR of the supplemented groups, excluding the positive control, was lower than that of the negative control group (Table 5). Both phytase addition (500 $\mathrm{PU} / \mathrm{g}$ ) and the elevated $\mathrm{P}$ level significantly $(\mathrm{P}<0.05)$ decreased the FCR, mainly, however, during the growing period (1737 days). Also in Trial 3, the FCR was decreased as a result of the supplementations; significant differences were not, however, found (Table 6). In previous studies with broiler chicks, feed intake rose markedly due to phytase supplementation but the FCR was not significantly affected (ZYLA et al. 1989, SimONS et al. 1990, Broz et al. 1992, SCHÖNER and HOPPE 1992, VoGT 1992a, b).

In Trial 1, supplemental phytase increased tibia length linearly $(\mathrm{P}<0.05)$ and the phosphorus content of tibia ash quadratically $(\mathrm{P}<0.001$, Table 4). Tibia ash values ranging from $54.8 \%$ to
$55.7 \%$ were not affected by phytase addition. In Trial 2, no differences in tibia length were found but differences in tibia ash between the negative control and the supplemented groups were clearer than in Trial 1, and the extreme values (negative and positive controls) differed significantly $(\mathrm{P}<0.001$, Table 5). The different responses to the supplementations in Trials 1 and 2 could have been due to the average lower available $\mathrm{P}$ content and lower natural phytase activity of the basal diet of Trial 2. The increase in mineral $\mathrm{P}$ from $0.05 \%$ to $0.10 \%$ increased the tibia ash content $(\mathrm{P}<0.05)$. Adding phytase or inorganic $\mathrm{P}$ or both to the basal diet with no mineral $\mathrm{P}$ supplementation promoted bone mineralization whether expressed as tibia weight, tibia length or tibia ash (Table 6, Trial 3). The tibia ash content was $51.0 \%$ for the non-supplemented group and 55.1-56.8\% for the supplemented groups. According to reports where the basal diet has contained $0.5 \%$ or less total phosphorus, phytase supplementations have increased the tibia ash content by 3-6 percentage units (KIISKINEN and PIIRONEN 1990, 
Broz et al. 1992, VoGt 1992a, b, FARrel et al. 1993). In the comparison with orthogonal contrasts, adding phytase to the diet with $0.05 \%$ mineral $\mathrm{P}$ increased tibia ash content linearly $(\mathrm{P}<0.05)$; the effect on tibia weight was nearly significant $(P=0.06)$. In contrast, mineral $P$ additions of up to $0.10 \%$ in the basal diet with no phytase addition increased all tibia values linearly $(\mathrm{P}<0.001)$ and tibia length $(\mathrm{P}<0.01)$ and tibia ash $(\mathrm{P}<0.001)$ quadratically.

Supplementations of the basal diet in Trial 3 resulted in a significant $(\mathrm{P}<0.05)$ increase in $\mathrm{P}$ and $\mathrm{Ca}$ retention due to increased feed intake and mineral supply (Table 6). The utilization of $\mathrm{P}$ (percentage retention of intake) increased by approximately 9 percentage units $(50.9 \% / 60.0 \%)$, when the basal diet was supplemented with phytase (1000 PU/g). Similar P utilization values of $50-60 \%$ and improvements of $5-15$ percentage units due to phytase supplementation have been reported in broiler chicks fed low phosphorus (0.35-0.5\%) diets (SIMONS et al. 1990, SсHÖNER and HOPPE 1992, SCHÖNER et al. 1993, FARRELL et al. 1993). When $0.05 \%$ mineral $\mathrm{P}$ was added to the basal diet, utilization of $\mathrm{P}$ did not change but additions of $0.10 \%$ and $0.30 \%$ mineral $\mathrm{P}$ reduced it to $42.3 \%$ and $33.9 \%$, respectively. Phytase supplementation did not affect retention or utilization of $\mathrm{P}$ when $0.05 \%$ or $0.10 \%$ mineral $\mathrm{P}$ was added to the diet. Phytase reduced the faecal P content from $7.7 \mathrm{~g} / \mathrm{kg}$ DM to $6.7 \mathrm{~g} / \mathrm{kg} \mathrm{DM}$ when added to the basal diet with no mineral $\mathrm{P}$ but did not have an effect in the diet with $0.05 \%$ mineral P. Supplementation of mineral P increased faecal $\mathrm{P}$ excretion linearly $(\mathrm{P}<0.001)$ from $2.3 \mathrm{~g}$ to $3.5,4.7$ and $7.2 \mathrm{~g}$ and faecal $\mathrm{P}$ content from $7.7 \mathrm{~g} / \mathrm{kg}$ DM to $8.5,10.5$ and $16.5 \mathrm{~g} / \mathrm{kg} \mathrm{DM}$ $(\mathrm{P}<0.001)$, respectively. When inorganic $\mathrm{P}(0.05$ and $0.10 \%$ ) was added to the diet, phytase did not affect faecal $\mathrm{P}$ or Ca excretion significantly. Compared with the positive control diet, savings in $\mathrm{P}$ excretion with the other supplemented diets were $35-64 \%$. According to HUYGHEBAERT and
DE Groote (1992), P excretion can be reduced by $30-50 \%$ by supplementing the diet with microbial phytase. Phytase supplementation (1000 $\mathrm{PU} / \mathrm{g}$ ) in the basal diet increased the utilization of Ca by 4.8 percentage units but the difference was not significant. This obervation is supported by certain other authors (SIMONS et al. 1990, SCHÖNER et al. 1991, 1993), who found that supplemental phytase markedly increased the utilization of $\mathrm{Ca}$ in low-calcium $(0.6 \%)$ diets. Addition of phytase to the diets with supplementation of $0.3 \%$ or $0.6 \%$ dicalcium phosphate did not affect the utilization of $\mathrm{Ca}$.

In addition to the intrinsic phytase activity derived from cereals, the results of this study were obviously affected by the calcium level and $\mathrm{Ca}: \mathrm{P}$ ratio of the diets. High dietary levels of $\mathrm{Ca}$ and high $\mathrm{Ca}: \mathrm{P}$ ratios cause a reduction in both feed consumption and body weight gains (V ANDEPOPULIERE et al. 1961, WALDROUP et al. 1964, NeLSON et al. 1965, EDWARDS 1982, SCHÖNER et al. 1993). An increased Ca content has been found to reduce the activity of phytase (McCuAIG et al. 1972 ) and the retention of $P$ from phytates (EDWARDS 1982, SCHÖNER et al. 1993). In the diets used here the Ca content was $0.8-1.0 \%$ and the $\mathrm{P}$ content of the basal diets $(0-0.1 \%$ mineral $\mathrm{P})$ was $0.44-0.60 \%$ (Ca:P $1.7-1.8)$. It is very probable that a lower $\mathrm{Ca}$ level of $0.6-0.7 \%$ would have given a better response to phytase addition. SCHÖNER et al. (1993) found that increasing the dietary Ca level from $0.6 \%$ to $0.9 \%$ in low-phosphorus diets had negative effects on the utilization of phosphorus.

Considering the results obtained here and the findings of earlier studies, we conclude that the weight gain of birds and $\mathrm{P}$ utilization and bone mineralization can all be improved by adding phytase to broiler diets composed of feed of plant origin and based on wheat, barley and oats. In this way, mineral $\mathrm{P}$ supplementation and $\mathrm{P}$ waste in manure can be reduced. 


\section{References}

Broz, J., Oldale, P., Rychen, G., Schulze, J. \& Simoes NUNES, C. 1992. Effects of supplemental phytase on performance and phosphorus utilization in broiler chickens reared until market weight. Proceedings 3, XIX World's Poultry Congress, Amsterdam. p. 435-438.

Chen, P.S.Jr., Toribara, T.Y. \& Warner, H. 1956. Microdetermination of phosphorus. Analytical Chemistry 28: 1756-1758.

EDWARDS, H.M.Jr. 1982. Phosphorus. 1. Effect of breed and strain on utilization of suboptimal levels of phosphorus in the ration. Poultry Science 62: 77-84.

Farrell, D.J., Martin, E., Thomson, E., Preez, J. du \& BongarTs, M. 1993. The beneficial effects of a microbial feed phytase in diets of broiler chickens and ducklings. Journal of Animal Physiology and Animal Nutrition 69: 278-283.

Huyghebaert, G. \& De Groote, G. 1992. The definition of Natuphos-5000 phytase in terms of relative P-values for least-cost formulation of broiler diets. Proceedings 3, XIX World's Poultry Congress, Amsterdam. p. 455-456.

KIISKINEN, T. 1983. The effect of diets supplemented with Regent rapeseed meal on performance of broiler chicks. Annales Agriculturae Fenniae 22: 206-213.

- \& Pitronen, J. 1990. Effects of phytase supplementation on utilization of phosphorus in chicken diets. Proceedings VIII European Poultry Conference, Barcelona. p. 376-380.

LANTZSCH, H.-J. 1990. Untersuchungen über ernährungsphysiologische Effekte des Phytats bei Monogastriern (Ratte, Schwein). Ûbersichten zur Tierernährung 18: 197-212.

McCuaig, L.W., Davies, M.I. \& MozoK, L. 1972. Intestinal alkaline phosphatase and phytase of chicks: Effect of dietary magnesium, calcium, phosphorus and thyroactive casein. Poultry Science 51: 526-530.

Milliken, G. \& Johnson, D. 1984. Analysis of Messy Data. Vol. 1: Designed experiments. 473 p. Van Nostrand Reinhold. New York.

Møllgaard, H., Lorengen, K., Hansen, I.G. \& ChrisTENSEN, P.E. 1946. On phytic acid, its importance in metabolism and its enzymic cleavage in bread supplemented with calcium. Biochemistry Journal 40: 589603.

Nelson, T.S., Ferrara, L.W. \& Storer, N.L. 1968a. Phytate phosphorus content of feed ingredients derived from plants. Poultry Science 47: 1372-1374.

-, Hargus, W.A., Storer, N. \& Walker, A.C. 1965. The influence of calcium on phosphorus utilization by chicks. Poultry Science 44: 1508-1513.

-, SHIEH, T.R., WodzINSKI, R.J. \& WARE, J.H. 1968 b. The availability of phytate phosphorus in soybean meal before and after treatment with a mold phytase. Poultry Science 47: 1842-1848.

-, SHIEH, T.R., WodzinSKI, R.J. \& WARE, J.H. 1971. Effect of supplemental phytase on the utilization of phytate phosphorus by chicks. Journal of Nutrition 101: 1289-1294.

NRC 1984. Nutrient Requirements of Poultry. 71 p. Eight Revised Edition. National Academy Press. Washington, D.C.

SAlo, M.-L., TuORI, M. \& KiISKInEN, T. 1990. Rehutaulukot ja ruokintanormit. 70 p. 3. Ed. Yliopistopaino. Helsinki.

SANDBERG, A.-S. \& AhDERINNE, R. 1986. HPLC method for determination of inositol tri-, tetra-, penta- and hexaphosphates in foods and intestinal contents. Journal of Food Science 51: 547-550.

SAS 1990. SAS/STAT User's Guide. 1686 p. Vers. 6, 4th ed., Vol. 2. SAS Inst. Inc. Cary, NC, USA.

- 1992. Technical Report P-229. SAS/STAT Software: Changes and Enhancements, Release 6.07: 620 p. SAS Inst. Inc. Cary, NC, USA.

SAYlor, W.W., BARTNIKowSKI, A. \& SPEnCER, T.L. 1991. Improved performance of broiler chicks fed diets containing phytase. Poultry Science 70. Supplement 1 p. 104 (Abstract).

SCHÖNER, F.J. \& HoPPE, P.P. 1992. Microbial phytase, a tool to alleviate environmental phosphorus pollution from broiler production. Proceedings 3, XIX World's Poultry Congress, Amsterdam. p. 429-432.

-, Hoppe, P.P. \& SchwarZ, G. 1991. Vergleich der Effekte von mikrobieller Phytase und anorganischem Phosphat auf die Leistungen und die Retention von Phosphor, Calcium und Rohasche bei Masthühnerküken in der Anfangsmast. Journal of Animal Physiology and Animal Nutrition 66: 248-255.

-, Hoppe, P.P., Schwarz, G. \& Wiesche, H. 1993. Vergleich von mikrobieller Phytase und anorganischem Phosphat bei Masthahnenküken: Wirkungen auf die Mastleistungen und die Mineralsroffretention bei varierter Calcium-Versorgung. Journal of Animal Physiology and Animal Nutrition 69: 235-244.

Simons, P.C.M., Versteegh, H.A.J., Jongbloed, A.W., Kemme, P.A., Slump, P., Bos, K.D., Wolters, M.G.E., BEUdEKER, R.F. \& VERSCHOOR, G.J. 1990. Improvement of phosphorus availability by microbial phytase in broilers and pigs. British Journal of Nutrition 64: 525-540.

SwICK, R.A. \& IvEY, F.J. 1990. Effect of dietary phytase addition on broiler performance in phosphorus deficient diets. Poultry Science 69. Supplement 1. p. 133 (Abstract).

VANDEPOPUliere, J.M., AmmermanN, C.B. \& HaRms, R.H. 1961. The relationship of calcium-phosphorus ratios on the utilization of plant and inorganic phosphorus by the chick. Poultry Science 40: 951-957.

VoGT, H. 1992a. Einsatz von Phytase im Broilermastfutter mit unterschiedlichem Phosphorgehalt. Archiv für Geflügelkunde 56: 93-98.

- 1992b. Einsatz von Phytase im Broilermastfutter mit unterschiedlichem Phosphorgehalt: 2. Versuch. Archiv 
für Geflügelkunde 56: 222-226.

Waldroup, P.W., Ammermann, C.B. \& Harms, R.H. 1964. The availability of phytic acid phosphorus for chicks. 3. Effect of calcium and vitamin $\mathrm{D}_{3}$ levels on the utilization of calcium phytate. Poultry Science 43: 926931.
ZYla, K., Koreleski, J. \& Kujawski, M. 1989. Dephosphorylation of phytate compounds by means of acid phosphatase from Aspergillus niger. Journal of the Science of Food and Agriculture 49: 315-324.

Manuscript received December 1993

\title{
SELOSTUS
}

\section{Fytaasilisäyksen vaikutukset broilerien rehussa}

\author{
Tuomo Kilskinen, Jari PiIronen ja TiIna Hakonen
}

Maatalouden tutkimuskeskus ja Oy Alko Ab

Sienifytaasin (Aspergillus niger) lisäyksen vaikutusta broileripoikasten (0-5,5 vk) kasvuun, rehunkulutukseen, luuston mineraalisoitumiseen ja fosforin hyväksikäyttöön tutkittiin kolmessa kokeessa, joissa oli yhteensä 5100 poikasta. Soija-viljapohjainen perusrehu sisälsi lisättyä kivennäisfosforia $0-0,1 \%$ (negatiivinen vertailurehu) entsyymilisäyksen ollessa 250-1000 fytaasiyksikköä (PU) rehugrammassa. Positiivisessa vertailurehussa kivennäisfosforin lisäys oli $0,24-0,30 \%$.

Fytaasin lisääminen perusrehuun, jossa ei ollut lainkaan tai hyvin vähän $(0,05 \%)$ lisättyä kivennäisfosforia, lisäsi selvästi broilerien rehunkulutusta ja kasvua. Fytaa- silisäyksellä $1000 \mathrm{PU} / g$ saavutettiin sama kasvutulos kuin positiivisella vertailurehulla. Sääriluusta tehdyt mittaukset ja määritykset osoittivat, ettei fytaasilisäyksellä ollut merkittävää vaikutusta luun mineralisoitumiseen, jos rehuun lisättiin kivennäisfosforia. Ellei rehuun lisätty kivennäisfosforia fytaasilisäyksen vaikutus sääriluuarvoihin oli huomattava. Fytaasilisäys (1000 PU/g) paransi fosforin hyväksikäyttöä perusrehussa ja vähensi fosforin erittymistä ulosteista. Koetulosten mukaan kivennäisfosforin käyttöä voidaan huomattavasti vähentää broilerien rehuissa lisäämällä niihin fytaasia, jolloin myös lannassa eritetty fosfori vähenee. 